\title{
Subcellular Localization of Inorganic Pyrophosphatases in Rabbit Skeletal Muscle and Some Properties of a Microsomal Acid Pyrophosphatase
}

\author{
Jun-ichiro Morita and Tsutomu YASUI \\ Department of Animal Science, Faculty of Agriculture, \\ Hokkaido University, Sapporo 060, Japan
}

Received October 4, 1984

\begin{abstract}
Subcellular localization of muscle inorganic pyrophosphatase was examined using rabbit skeletal muscle homogenates. The pyrophosphatases were found to be contained in the microsomal, mitochondrial, and cytosol fractions. The microsomal and mitochondrial pyrophosphatases were most likely bound to the respective subcellular fractions. The pyrophosphatases associated with microsome and mitochondria showed their optimal activities at about $\mathrm{pH} 5.5$ and 7 , respectively. They were not dissociated from the particles by washing with salt solution or by ten times freezing-thawing. The activity of microsomal acid pyrophosphatase was not affected by $\mathrm{Mg}^{2+}{ }^{2} \mathrm{Ca},{ }^{2+}$ or EDTA, but that of the mitochondrial neutral pyrophosphatase was enhanced by the addition of $\mathrm{Mg}^{2+}$ The microsomal acid pyrophosphatase was stable between $\mathrm{pH}$ values of 5.5 and 8.5 during storage at $4{ }^{\circ} \mathrm{C}$. The activity was inhibited by $p$-chloromercuribenzoate. The activity was irreversibly inhibited by sodium dodecyl sulfate, but reversibly inhibited by neutral salts and membrane solubilizing detergents such as Triton X-100, octaethylene glycol mono- $n$-dodecylether, and sodium cholate.
\end{abstract}

Pyrophosphate (PP) is a product of many biosynthetic reactions. PP has been suggested to regulate many metabolic reactions and to pull in the biosynthetic direction by hydrolysis of PP by inorganic pyrophosphatase (EC 3.6.1.1, PPase). ${ }^{1,2)}$ Not a few PPases are widely distributed in different cells where they enhance many PP producing reactions. There have been many studies on these enzymes isolated from a variety of sources. ${ }^{3,4)}$ They were found in mammalian cells of some organs such as liver, ${ }^{5,6)}$ brain, ${ }^{7,8)}$ and leucocytes ${ }^{9)}$ and their subcellular localization has been established in these organs. The PPase activity in mitochondria, lysosomes, or microsomes of rat liver ${ }^{6,10,11)}$ and in rat and bovine heart mitochondria ${ }^{11,12)}$ was also reported.

Little is known about the PPases in skeletal muscle cells. Previous studies had shown that PP added to muscle homogenates was hydrolyzed by the enzyme(s), which were present intrinsically in skeletal muscles. ${ }^{13,14)}$ The hydrolytic activity showed two $\mathrm{pH}$ optima at $\mathrm{pH}$
5.5 and 7. Some properties of a purified neutral PPase in the cytosol fraction of muscle were already reported. ${ }^{15)}$ This paper presents the results of investigation on subcellular localization of these PPases in muscle and some properties of an acid PPase of the microsomal fraction.

\section{MATERIALS AND METHODS}

Materials. The sources of materials used in this work were as follows: dithiothreitol (DTT), sodium deoxycholate (DOC), sodium cholate, sodium salt glucose-6phosphate (G-6-P), sodium salt $\beta$-glycerophosphate, ferro cytochrome $c$, and bovine serum albumin from Sigma Chemical Co., scintillation-grade Triton X-100 from Eastman Kodak Co., histidine, imidazole, Tris(hydroxymethyl)aminomethane (Tris), p-chloromercuribenzoate acid (pCMB), sodium dodecyl sulfate (SDS), and sodium pyrophosphate (Na-PP) from Nakarai Chemicals Co., octaethylene glycol mono- $n$-dodecylether $\left(\mathrm{C}_{12} \mathrm{E}_{8}\right)$ from Nikko Chemicals Co., and Milpap filter paper from Azumi Roshi Co. All other reagents were of the purest grade commercially available. 
Enzyme assay. The PPase assay was done by adding substrate after preincubation at $25^{\circ} \mathrm{C}$ for $7 \mathrm{~min}$ and the reaction was stopped by adding $2 \mathrm{ml}$ of $16 \%$ trichloroacetic acid (TCA) to $2 \mathrm{ml}$ of the reaction mixture. The PPase activity was determined by measuring the Pi liberated in the reaction mixture according to the method of Martin and Doty ${ }^{16)}$ with a slight modification. ${ }^{17)}$ The composition of the assay mixture is described in the legend of each figure. The specific activity was expressed in units (U) defined as $\mu \mathrm{mol}$ of Pi liberated in $1 \mathrm{hr}$ by $1 \mathrm{mg}$ of protein.

The G-6-P phosphatase activity in muscle samples was measured by the method of De Duve et al. ${ }^{18)}$ at $37^{\circ} \mathrm{C}$ in a reaction mixture containing $0.25 \mathrm{M}$ sucrose, $9 \mathrm{~mm}$ G-6-P, $1 \mathrm{~mm}$ EDTA, and $20 \mathrm{~mm}$ histidine- $\mathrm{NaOH}$ buffer, $\mathrm{pH}$ 6.5. The reaction was stopped by the addition of TCA and the inorganic Pi content was determined in the filtrate.

The $\beta$-glycerophosphatase activity in muscle samples was measured at $37^{\circ} \mathrm{C}$ in a reaction mixture containing $0.25 \mathrm{~m}$ sucrose, $20 \mathrm{~mm} \beta$-glycerophosphate, and $0.1 \mathrm{M}$ sodium acetate buffer, $\mathrm{pH} 5.0 .^{19,20)}$

The cytochrome $c$ oxidase activity in muscle samples was measured by the method of Wharton and Tzagoloff ${ }^{21}$ ) using a Hitachi recording spectrophotometer, model 323. The incubation mixture contained $0.25 \mathrm{M}$ sucrose, $0.07 \%$ ferro cytochrome $c$, and $10 \mathrm{~mm}$ potassium phosphate buffer, $\mathrm{pH} 7.2$. The change in optical density at $550 \mathrm{~nm}$ was followed at $25^{\circ} \mathrm{C}$.

The cathepsin activity in muscle samples was measured by the method of $\mathrm{Mycek}^{22)}$ at $37^{\circ} \mathrm{C}$ in a reaction mixture containing $0.25 \mathrm{M}$ sucrose, $1 \%$ bovine serum albumin, and $0.15 \mathrm{M}$ sodium acetate buffer, $\mathrm{pH}$ 5.0. The reaction was stopped by the addition of TCA, and the reaction mixture was filtered with Whatman No. 3 filter paper. The peptides produced in the filtrate were measured by the method of Lowry et al. $^{23)}$

Tissue fractionation. Homogenates of muscle from rabbits were fractionated by a differential centrifugation method similar to that of De Duve et al. ${ }^{18)}$ Two hundred grams of fresh minced muscle from rabbits was mixed with $800 \mathrm{ml}$ of chilled $0.01 \mathrm{M}$ histidine- $\mathrm{NaOH}$ buffer solution (pH 6.4) containing $0.25 \mathrm{M}$ sucrose and $0.1 \mathrm{~mm}$ EDTA. The mixture was homogenized with a Hitachi model VA835 homogenizer at $12,000 \mathrm{rpm}$ for $1 \mathrm{~min}$. The resulting slurry was centrifuged in the cold at $500 \times g$ for $10 \mathrm{~min}$. The precipitate, which still contained a large amount of unbroken muscle cells, was rehomogenized in about the same quantity of the buffer and centrifuged. The sum of the supernatants of two centrifugation was centrifuged at $1000 \times g$ for $10 \mathrm{~min}$. Observation under a microscope showed that there were a few fragmented myofibrils besides nuclei in the precipitate. From this supernatant, mitochondrial (M), lysosomal (L) heavy microsomal (Ms1), intermediate microsomal (Ms-2), and light microsomal (Ms-3) fractions were isolated by differential centrifugation at $5,000 \times g$ for $10 \mathrm{~min}, 8,500 \times g$ for $10 \mathrm{~min}$,
$12,000 \times g$ for $30 \mathrm{~min}, 20,000 \times g$ for $40 \mathrm{~min}$, and $105,000 \times$ $g$ for $60 \mathrm{~min}$, respectively. These fractions were dispersed with the above buffer solution in a Teflon homogenizer of the Potter-Elvejhem type and centrifuged at $105,000 \times g$ for $30 \mathrm{~min}$ twice. Similarly, the nuclear fraction was dispersed with 3 volumes of the above medium and centrifuged at $1,000 \times g$ for $10 \mathrm{~min}$. This washing procedure was repeated several times to obtain a rather light nuclear fraction.

A bulk microsomal fraction was prepared by a similar procedure as described above with slight modifications. To $100 \mathrm{~g}$ of fresh minced muscle, $300 \mathrm{ml}$ of $0.01 \mathrm{M}$ histidine$\mathrm{NaOH}$ buffer ( $\mathrm{pH}$ 6.4) containing $0.25 \mathrm{~m}$ sucrose was added, the sample was homogenized at $12,000 \mathrm{rpm}$ for 2 to $3 \mathrm{~min}$ in a homogenizer cup equipped with an ice-jacket, and the slurry was centrifuged at $2,600 \times g$ for $20 \mathrm{~min}$. The precipitate was rehomogenized as it semed to contain a large amount of unbroken cells. The resulting supernatant was filtered through cheesecloth or Milpap filter paper, and centrifuged again at $10,000 \times g$ for $15 \mathrm{~min}$ to remove mitochondrial and lysosomal fractions. The microsomal fraction was collected by centrifugation at $100,000 \times g$ for $60 \mathrm{~min}$ or by acid precipitation from the supernatant of the centrifugaton at $10,000 \times g$. In the latter case, the $\mathrm{pH}$ of the supernatant was adjusted to 5.4 with $3 \mathrm{~N}$ acetic acid. Immediately after the adjustment of $\mathrm{pH}$, the turbid supernatant was centrifuged at $2,600 \times g$ for $20 \mathrm{~min}$. The precipitated microsomal fraction was dispersed in a solution consisting of $0.25 \mathrm{M}$ sucrose, $10 \mathrm{~mm}$ Tris- $\mathrm{HCl}$ buffer, $\mathrm{pH}$ 7.5, and $1 \mathrm{~mm}$ EDTA (Buffer A) using a Teflon homogenizer and the $\mathrm{pH}$ was adjusted to 7.5 with $0.1 \mathrm{~N} \mathrm{NaOH}$. After slow stirring for $1 \mathrm{hr}$ at $4^{\circ} \mathrm{C}$, the solution was centrifuged at $10,000 \times g$ for $60 \mathrm{~min}$. This washing procedure by dispersing and centrifuging was repeated once more. The final washed microsomal precipitate was dispersed in Buffer A (washed microsomes) and stored in an icecold bath until used for further experimentation.

Other methods. Protein concentrations of the subcellular fractions were measured by the method of Lowry et al. ${ }^{23}$ ) with bovine serum albumin as a reference standard. Cholic acids were recrystallized from $70 \%$ ethanol.

\section{RESULTS AND DISCUSSION}

\section{PPase activity in subcellular fractions of skele- tal muscle}

The subcellular fractions of skeletal muscle cells were prepared by differential centrifugation by the method of De Duve et al. ${ }^{18)}$ Figure 1 shows the plots of the PPase activity of the different subcellular fractions obtained from $200 \mathrm{~g}$ of the muscle as a function of $\mathrm{pH}$. Nuclei and the small myofibril fraction had little PPase activity at $\mathrm{pH} 4.0$ to 7.2 . The PPase 


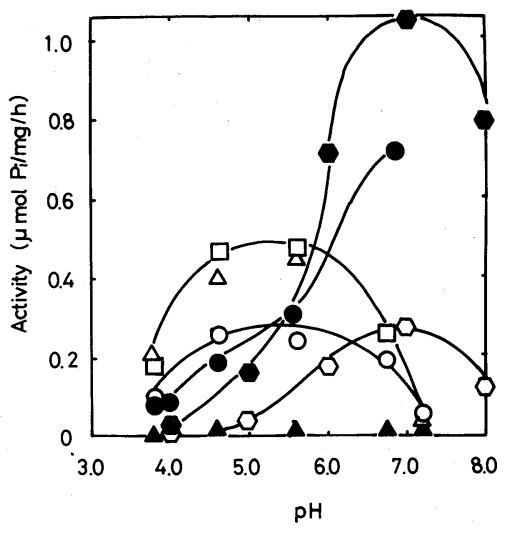

FIG. 1. Plot of the Pyrophosphatases Activity of Subcellular Fractions of Rabbit Muscle Cells vs. $\mathrm{pH}$.

$\mathrm{O}$, Fraction containing mitochondria and lysosomes (14.4 mg protein $/ \mathrm{ml}-20 \mathrm{ml}$ ) without $\mathrm{MgCl}_{2}$;, , fraction containing mitochondria and lysosomes with $\mathrm{MgCl}_{2} ; \square$, fraction containing heavy microsomes $(7.1 \mathrm{mg}$ protein $/ \mathrm{ml}$ $15 \mathrm{ml})$ with $\mathrm{MgCl}_{2} ; \triangle$, fraction containing light microsomes $(8.5 \mathrm{mg}$ protein $/ \mathrm{ml}-15 \mathrm{ml})$ with $\mathrm{MgCl}_{2} ; \boldsymbol{\Delta}$, fraction containing nuclei and fragmented myofibrils $(20 \mathrm{mg}$ protein $/ \mathrm{ml}-240 \mathrm{ml}$ ) with $\mathrm{MgCl}_{2} ; 0$, soluble fraction $(9.5$ $\mathrm{mg}$ protein $/ \mathrm{ml}-760 \mathrm{ml}$ ) without $\mathrm{MgCl}_{2}$;, , soluble fraction with $\mathrm{MgCl}_{2}$. Reaction mixture consisted of $0.25 \mathrm{M}$ sucrose, $0.08 \mathrm{M}$ buffer, $1 \mathrm{mM} \mathrm{Na}-\mathrm{PP}$, and 0 or $2.5 \mathrm{mM} \mathrm{MgCl}_{2}$. Buffers were: sodium acetate, $\mathrm{pH} 4 \sim 5.5$; histidine$\mathrm{NaOH}, \mathrm{pH} 6.0 \sim 6.5$; imidazole- $\mathrm{HCl}, \mathrm{pH} 7.0 \sim 7.5$; Tris$\mathrm{HCl}, \mathrm{pH} 7.2 \sim 8.5$.

activity of mitochondria and the lysosome fraction had optima in neutral and acidic $\mathrm{pH}$, in the presence and absence of $\mathrm{MgCl}_{2}$, respectively. The PPase activity of light and heavy microsomal fractions had an optimum at $\mathrm{pH}$ 5.5. The PPase of the soluble fraction had an optimum at $\mathrm{pH} 7.2$, and $\mathrm{MgCl}_{2}$ activated it as reported previously. ${ }^{15)}$ These results show that neutral PPase is contained also in the mitochondrial or lysosomal fractions, whereas acid PPase is present in the lysosomal or microsomal fraction.

Activities of some marker enzymes were assayed to examine whether each fraction was finely separated by this method. Figure 2 shows the subcelluar distribution of total acid PPase and marker enzyme activities. Cytochrome $c$ oxidase, acid cathepsin (and $\beta$ glycerophosphatase), and G-6-P phosphatase were employed as marker enzymes for the mitochondrial, lysosomal, and microsomal

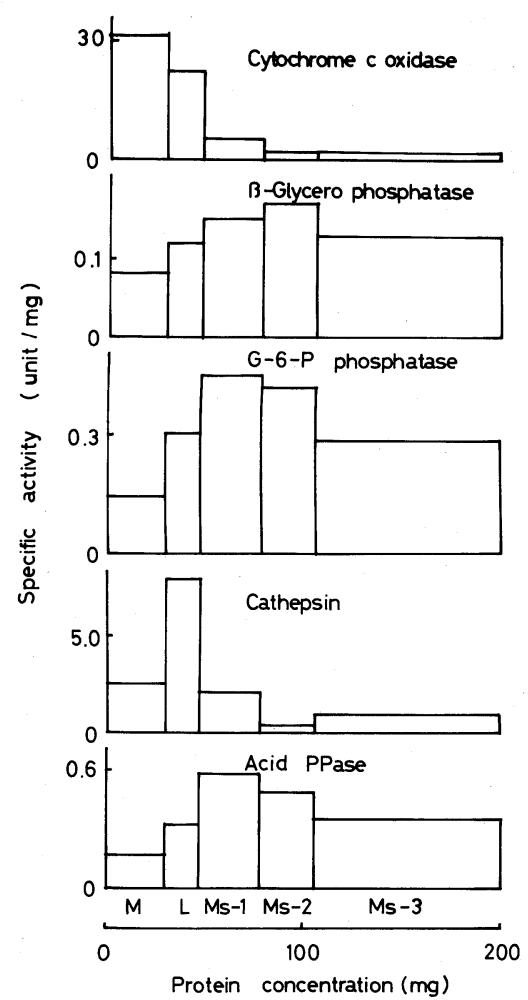

FIG. 2. Subcellular Distribution of Acid PPase and Some Marker Enzymes.

Acid PPase activity was assayed in the mixture containing $0.25 \mathrm{M}$ sucrose, $0.5 \mathrm{~mm}$ EDTA, $1 \mathrm{~mm} \mathrm{Na}-\mathrm{PP}$; and $0.1 \mathrm{M}$ sodium acetate buffer, $\mathrm{pH}$ 5.5. Abbreviations and assay conditions for the maker enzymes are described in Materials AND Methods.

fractions, respectively. The specific activities were plotted on the basis of protein content according to the procedure of De Duve et al. ${ }^{18)}$ Since nuclei could not be completely separated from fragmented short myofibrils and since the soluble neutral PPase activity was contained in the cytosol fraction (Fig. 1), these fractions were omitted from Fig. 2. Although much $\beta$ glycerophosphatase was also found in the microsomal fraction, cytochrome $c$ oxidase and cathepsin were found exclusively in the mitochondrial and lysosomal fractions, respectively. Therefore, it was presumed that we succeeded in separating the subcellular fractions from the muscle homogenate. The intracellular distribution pattern of acid PPase was similar to that of G-6-P phosphatase, but 
not to those of cathepsin and other marker enzymes. These results show a large amount of acid PPase is in the microsomal fraction.

Rafter $^{24)}$ reported that a mitochondrial fraction prepared from mouse liver by centrifugation between $600 \times g$ for $15 \mathrm{~min}$ and $8,500 \times g$ for $15 \mathrm{~min}$ showed PPase activity, the maximum being at $\mathrm{pH}$ 5.3, without requiring $\mathrm{Mg}^{2+}$ ion. Nordlie and Lardy ${ }^{6}$ reported that nuclear, mitochondrial, and microsomal fractions from rat liver contained significant amounts of PPase activity, that the activity of the nuclear fraction was due to contamination with erythrocytes, and that acid PPase appeared in the microsome fraction. Stetten and Burnet ${ }^{25)}$ reported that PPase was contained in rat-liver microsomes, and was activated by treatment with ammonium or amino acid buffer at $\mathrm{pH} 9.5 \sim 9.8$ or by treatment with DOC or Triton X-100. Soodsma and Nordlie ${ }^{26)} \mathrm{de}$ tected a small amount of PPase activity in particulate fractions of rat heart at $\mathrm{pH} 7.5$ in the presence of $\mathrm{Mg}^{2+}$, besides $\mathrm{Mg}^{2+}$ stimulated activity in the soluble fraction. Our results using rabbit skeletal muscles (Figs. 1 and 2) are consistent with those of Nordlie and Lardy. That is, the neutral PPase activity was found in the mitochondrial and soluble fractions in the presence of $\mathrm{MgCl}_{2}$, and the bulk of acid PPase activity was in the microsomal fraction without latency.

Brightwell and Tappel ${ }^{10)}$ purified from ratliver and kidney lysosomal fractions an acid PPase that could hydrolyze ATP and other nucleoside triphosphates, PP, thiamine diphosphate, and FAD. They also noticed that the activity of lysosomal PPase had latency, i.e., the enzymatic activity could be released from the lysosomal fractions to a soluble state by freeze-thawing or sonication. Microsomal PPase obtained from rabbit muscle in this study did not show any latency even though freezing and thawing was repeated ten times.

With regard to mitochondrial PPase, Schick and Butler ${ }^{11)}$ found the activity at $\mathrm{pH} 5$ and $\mathrm{pH} 7 \sim 8$ in the presence of $\mathrm{Mg}^{2+}$ in the intact mitochondria (overt) from rat-liver. $\mathrm{Mg}^{2+}$ was not required for the activity of acid PPase. However, the $\mathrm{Mg}^{2+}$-dependent neutral or alkaline PPase activity was stimulated several fold by disruption of mitochondrial membranes by sonication. They assumed from this latency that the enzyme was inside the inner membrane. Irie et al. ${ }^{27)}$ partly purified two different alkaline PPases from mitochondria of rat liver. These were different with respect to $\mathrm{Mg}^{2+}$ requirement, substrate specificity, and inactivation by urea. Rabbit-muscle mitochondria in this study also showed neutral or alkaline PPase activity which was enhanced by the addition of $\mathrm{Mg}^{2+}$ (Fig. 1). The mitochondria were washed by dispersing $10 \mathrm{~mm}$ histidine- $\mathrm{NaOH}$ buffer ( $\mathrm{pH}$ 6.4) containing $0.15 \mathrm{M} \mathrm{NaCl}$ and centrifuging. The washing did not remove the PPase activity from the fraction. The PPase was not released from mitochondria by ten freeze-thawing operations. These results suggest that an intrinsic PPase is associated with the mitochondrial membrane of rabbit muscle cells.

\section{Effects of $p H$}

The washed microsomal fraction contained

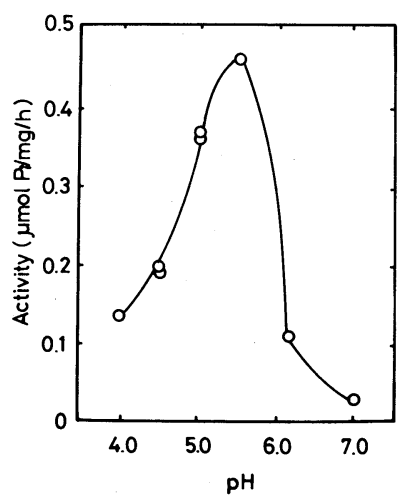

FIG. 3. Effects of $\mathrm{pH}$ on the Activity of Muscle Microsomal PPase.

The reaction mixture was $1 \mathrm{~mm} \mathrm{Na-PP,} 5 \mathrm{mg} / \mathrm{ml}$ microsomal protein, and buffers. For $\mathrm{pH}$ control, $0.2 \mathrm{M}$ sodium acetate ( $\mathrm{pH} 4.0$ to 5.5 ), $0.165 \mathrm{M}$ histidine- $\mathrm{NaOH}$ ( $\mathrm{pH} 6.16$ ), and $0.2 \mathrm{M}$ imidazole- $\mathrm{HCl}(\mathrm{pH} 7.0)$ buffers were used. Preincubation was for $5 \mathrm{~min}$ at $25^{\circ} \mathrm{C}$. 


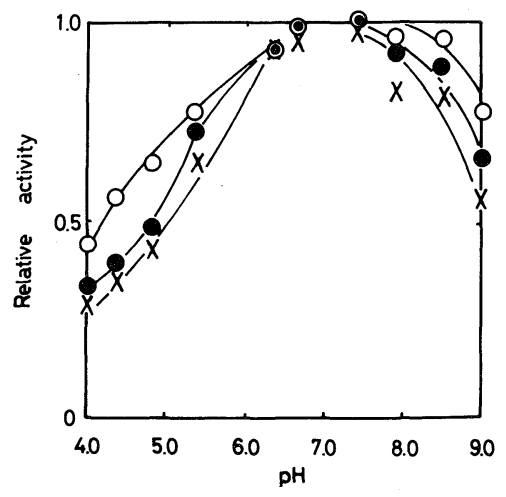

Fig. 4. Effects of $\mathrm{pH}$ on the Stability of Microsomal Acid PPase.

The microsomal fraction was incubated in a solution containing $5 \mathrm{mM} \mathrm{MgCl}_{2}$ and $40 \mathrm{mM}$ of various buffers for $44 \mathrm{hr}(\mathrm{O}), 90 \mathrm{hr}(\mathrm{O})$, and $136 \mathrm{hr}(\times)$ at $4{ }^{\circ} \mathrm{C}$ and the activity was then assayed at $\mathrm{pH} 5.5$ in a reaction mixture containing $5 \mathrm{mM} \mathrm{MgCl}, 1 \mathrm{~mm} \mathrm{Na}-\mathrm{PP}$, and $0.2 \mathrm{M}$ sodium acetate buffer. The reaction mixture was preincubated for $5 \mathrm{~min}$ at $25^{\circ} \mathrm{C}$. Buffers used were sodium acetate $(\mathrm{pH} 4.0$ to 5.5), histidine- $\mathrm{NaOH}$ ( $\mathrm{pH} 6.16$ to 6.5 ), imidazole- $\mathrm{HCl}$ (pH 7.0), and Tris- $\mathrm{HCl}(\mathrm{pH} 7.5$ to 8.5$)$.

only acid PPase activity. Figure 3 shows that the $\mathrm{pH}$-activity curve has a bell shape and the maximum activity is at about $\mathrm{pH} 5.5$ in sodium acetate buffer. At pH 7.0, a little activity was shown. These results are in good agreement with those of Nordlie and Lardy ${ }^{6}$ and are similar to those of rat-liver mitochondrial PPase in the absence of $\mathrm{MgCl}_{2}{ }^{11)}$ The data in Fig. 3 suggest that carboxyl and imidazolium groups may be involved in the active sites, ${ }^{28)}$ but further studies on the $\mathrm{pH}$-dependency of the maximum velocity or Michaelis constant will be required.

The microsomal acid PPase was stable at $\mathrm{pH}$ values between 5.5 to 8.5 at $4{ }^{\circ} \mathrm{C}$, and the activity was not changed between $\mathrm{pH} 6.5$ to 7.5 during incubation for $136 \mathrm{hr}$ (Fig. 4).

\section{Effects of divalent cations, EDTA, and ionic} strength on the acid PPase activity

Unlike neutral water-soluble PPase $A,{ }^{15)}$ the acid PPase activity was not affected by the addition of divalent cations such as $\mathrm{Mg}^{2+}$ and $\mathrm{Ca}^{2+}$, or by EDTA. These properties are similar to those of the enzymes in rat-heart microsomes, ${ }^{26)}$ mouse-liver mitochondria, ${ }^{24)}$

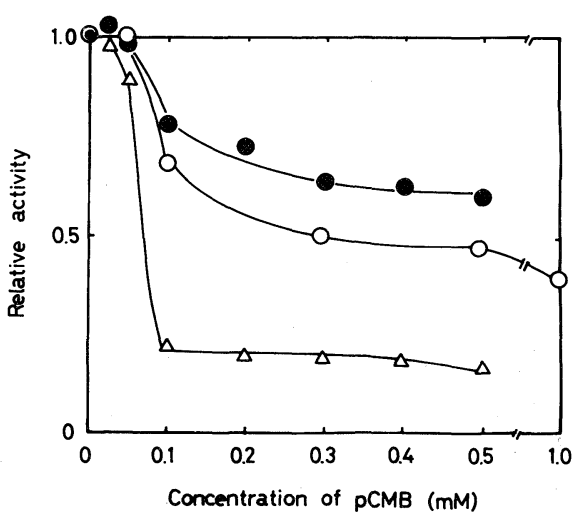

FIG. 5. Effects of Sulfhydryl Reagents on the Activity of Muscle Microsomal Acid PPase.

Activity was assayed in the presence of $1 \mathrm{mg} / \mathrm{ml}$ microsomal protein, $0.25 \mathrm{M}$ sucrose, $5 \mathrm{~mm}$ EDTA, $0.1 \mathrm{M}$ sódium acetate buffer, pH 5.5, $1 \mathrm{~mm} \mathrm{Na-PP}$, and pCMB at $25^{\circ} \mathrm{C}$ after incubation at $4^{\circ} \mathrm{C}$ for $90 \mathrm{~min}$ and preincubation at $25^{\circ} \mathrm{C}$ for $5 \mathrm{~min}(\mathrm{O})$. Incubation mixture containing $2 \mathrm{mg} / \mathrm{ml}$ microsomal protein, $0.25 \mathrm{M}$ sucrose, $5 \mathrm{~mm}$ EDTA, $0.1 \mathrm{M}$ sodium acetate buffer, $\mathrm{pH} 5.5$, and 2-fold concentration of pCMB shown on the abscissa was diluted to the above reaction mixture with $(\odot)$ or without $(\triangle) 10 \mathrm{~mm}$ DTT after $17 \mathrm{hr}$ at $4^{\circ} \mathrm{C}$.

and in rat-liver and rat-kidney lysosomes. ${ }^{10)}$ Relative activity was slightly decreased in the presence of excessive divalent metals $(20 \mathrm{~mm})$. The activity of microsomal acid PPase decreased with increasing the concentration of $\mathrm{NaCl}$ in the reaction mixture.

\section{Effects of sulfhydryl reagents}

As shown in Fig. 5, the microsomal acid PPase activity was inhibited over $80 \%$ after incubation for $17 \mathrm{hr}$ at $4{ }^{\circ} \mathrm{C}$ in the presence of $0.1 \mathrm{~mm}$ or more of $\mathrm{pCMB}$, but this inhibition was suppressed by the addition of excess DTT. Probably the sulfhydryl group(s) make some contribution to the active site of the enzyme, we have concluded pending the examination of the correlation between $\mathrm{SH}$ content and the activity.

\section{Effects of detergents on the activity}

Many surfactants have been used to solubilize enzymes which are bound to membranes. Among them, ionic detergents such as SDS and cholic acid, or nonionic detergents such as Triton X-100 and $\mathrm{C}_{12} \mathrm{E}_{8}$ are frequently 


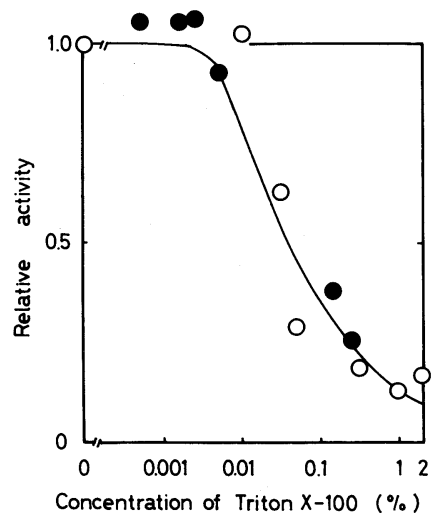

FIG. 6. Effect of Triton X-100 on the Activity of Microsomal Acid PPase from Rabbit Skeletal Muscle.

Microsomal fraction ( $10 \mathrm{mg} / \mathrm{ml}$ protein) was incubated in the solution containing $0.25 \mathrm{~m}$ sucrose, $5 \mathrm{~mm}$ EDTA, $10 \mathrm{~mm}$ Tris- $\mathrm{HCl}$ buffer ( $\mathrm{pH} 7.2$ ), and Triton $\mathrm{X}-100$ shown on the abscissa $(O)$ or 20 -fold concentration of Triton $\mathrm{X}$ 100 shown (O) with occasional mixing for $20 \mathrm{hr}$ at $4^{\circ} \mathrm{C}$. The activity was measured at $25^{\circ} \mathrm{C}$ in the reaction mixture containing $1 \mathrm{mg} / \mathrm{ml}(\mathrm{O})$ or $0.5 \mathrm{mg} / \mathrm{ml}(\bigcirc)$ microsomal protein, $1 \mathrm{~mm} \mathrm{Na-PP,} 0.25 \mathrm{M}$ sucrose, $5 \mathrm{~mm}$ EDTA, $0.1 \mathrm{M}$ sodium acetate buffer ( $\mathrm{pH} 5.5$ ), and Triton $\mathrm{X}-100$ at the final levels shown on the abscissa.

used. $^{29 \sim 31)}$ Before using these detergents, it is necessary to examine whether they denature the enzyme. Therefore, the effect of some detergents on the activity of microsomal acid PPase was examined. The acid PPase was irreversibly inactivated by the addition of SDS. However, the changes in the acid PPase activity by the addition of detergents such as Triton X-100, $\mathrm{C}_{12} \mathrm{E}_{8}$, sodium cholate, or DOC were reversible; relative activity decreased with increasing concentrations of Triton X-100, but the PPase activities were almost identical with those found on incubation in the solutions containing the low concentration of detergent when the PPase was transferred into solutions of low concentration of detergent from high concentrations after incubation for $20 \mathrm{hr}$ at $4^{\circ} \mathrm{C}$ (Fig. 6).

Membrane-bound PPase in Rhodospirillum rubrum is coupled to the electron transport chain in chromatophores and it catalyzes the hydrolysis and synthesis of PP. ${ }^{32)}$ The membrane-bound PPase in eucaryotes is closely related to PP synthesis coupled to the mito- chondrial respiratory chain. ${ }^{33)}$ Thus it is of considerable interest to study the role of microsomal PPase in muscle cells. Using the above detergents, we are now progressing in separating the acid PPase from the microsomal membrane.

Acknowledgment. We are grateful to Dr. Ali Asghar for reading this manuscript.

\section{REFERENCES}

1) A. Kornberg, "Horizons in Biochemistry," ed. by M. Kasha and B. Pullman, Academic Press Inc., New York, N.Y., 1962, p. 251.

2) A. L. Lehninger, "Biochemistry," Worth Publishers Inc., New York, N.Y., 1975, pp. 411, 546, 640, and 934.

3) L. G. Butler, "The Enzymes," 3rd Ed., Vol. 4, ed. by P. D. Boyer, Academic Press Inc., New York, N.Y., 1971, p. 529.

4) R. Lahti, Microbial. Rev., 47, 169 (1983).

5) A. Horn, H. Bornig and G. Thiele, Eur. J. Biochem., 2, 243 (1967).

6) R. C. Nordlie and H. A. Lardy, Biochim. Biophys. Acta, 50, 189 (1961).

7) A. Hachimori, T. Fujii, K. Ohki and E. Iizuka, $J$. Biochem., 93, 257 (1983).

8) U. S. Seal and F. Binkley, J. Biol. Chem., 228, 193 (1957).

9) K. B. Raja, G. P. Smith and T. Peters, Clinica Chimica Acta, 117, 33 (1981).

10) R. Brightwell and A. L. Tappel, Arch. Biochem. Biophys., 124, 333 (1968).

11) L. Schick and L. G. Butler, J. Cell Biology, 42, 235 (1969).

12) S. E. Volk, A. A. Baykov, V. S. Duzhenko and S. M. Avaeva, Eur. J. Biochem., 125, 215 (1982).

13) S. Nakamura, M. Yamaguchi, J. Morita and T. Yasui, J. Agr. Food Chem., 17, 633 (1969).

14) J. Morita, T. Nagahashi, A. Tanizaki and T. Yasui, J. Fac. Agr. Hokkaido Univ., 61, 351 (1983).

15) J. Morita and T. Yasui, J. Biochem., 83, 719 (1978).

16) J. B. Martin and D. M. Doty, Anal. Chem., 21, 965 (1949).

17) Y. Takahashi, Seikagaku (in Japanese), 26, 690 (1955).

18) C. De Duve, B. C. Pressman, R. Gianetto, R. Wattiaux and F. Appelmans, Biochem. J., 60, 604 (1955).

19) R. Gianetto and C. De Duve, Biochem. J., 59, 433 (1955).

20) S. Shibko and A. L. Tappel, Biochem. J., 95, 731 (1965).

21) D. C. Wharton and A. Tzagoloff, "Methods in Enzymology," Vol. 10, ed. by R. W. Estabrook and 
M. E. Pullman, Academic Press Inc., New York, N.Y., 1967, p. 245.

22) M. J. Mycek, "Methods in Enzymology," Vol. 19, ed. by G. E. Perlmann and L. Lorand, Academic Press Inc., New York, N.Y., 1970, p. 285.

23) O. H. Lowry, N. J. Rosebrough, A. L. Farr and R. J. Randal, J. Biol. Chem., 193, 265 (1951).

24) G. W. Rafter, J. Biol. Chem., 230, 643 (1954).

25) M. R. Stetten and F. F. Burnett, Biochim. Biophys. Acta, 128, 344 (1966).

26) J. F. Soodsma and R. C. Nordlie, Biochim. Biophys. Acta, 122, 510 (1966).

27) M. Irie, A. Yabuta, K. Kimura, Y. Shindo and K.
Tomita, J. Biochem., 67, 47 (1970).

28) M. Dixon and E. C. Webb, "Enzymes," 3rd Ed., Longman Group Ltd., London, 1979, p. 138.

29) S. A. Cohen, R. Sterner, P. S. Keim and R. L. Heinrikson, J. Biol. Chem., 253, 889 (1978).

30) A. Helenius and K. Simons, Biochim. Biophys. Acta, 415, 29 (1975).

31) W. L. Dean and C. Tanford, J. Biol. Chem., 252, 3551 (1977).

32) M. Baltscheffsky, Biochem. Biophys. Res. Commun., 28, 270 (1967).

33) S. E. Mansurova, Y. A. Shakhov and I. S. Kulaev, FEBS Lett., 74, 31 (1977). 